\title{
Socio-Demographic Profile of HIV Patients at Seti Zonal Hospital
}

\author{
Paudel BN, ${ }^{1}$ Sharma $S,{ }^{2}$ Singh GB, ${ }^{3}$ Dhungana GP, ${ }^{4}$ Paudel $P^{5}$ \\ ${ }^{1}$ Department of Medicine, Seti Zonal Hospital, Dhangadhi, Kailali, ${ }^{2}$ Department of Medicine and Chief of HIV unit, \\ Tribhuvan University, Teaching Hospital Kathmandu, ${ }^{3}$ Department of Gynae/obs, Seti Zonal Hospital, Dhangadi, Kailali, \\ ${ }^{4}$ Departmnent of Microbiology, Siddhanath science campus, Mahendranagar, Kanchanpur, ${ }^{5}$ Paropakar Hospital, Thapathali, \\ Kathmandu
}

\section{ABSTRACT}

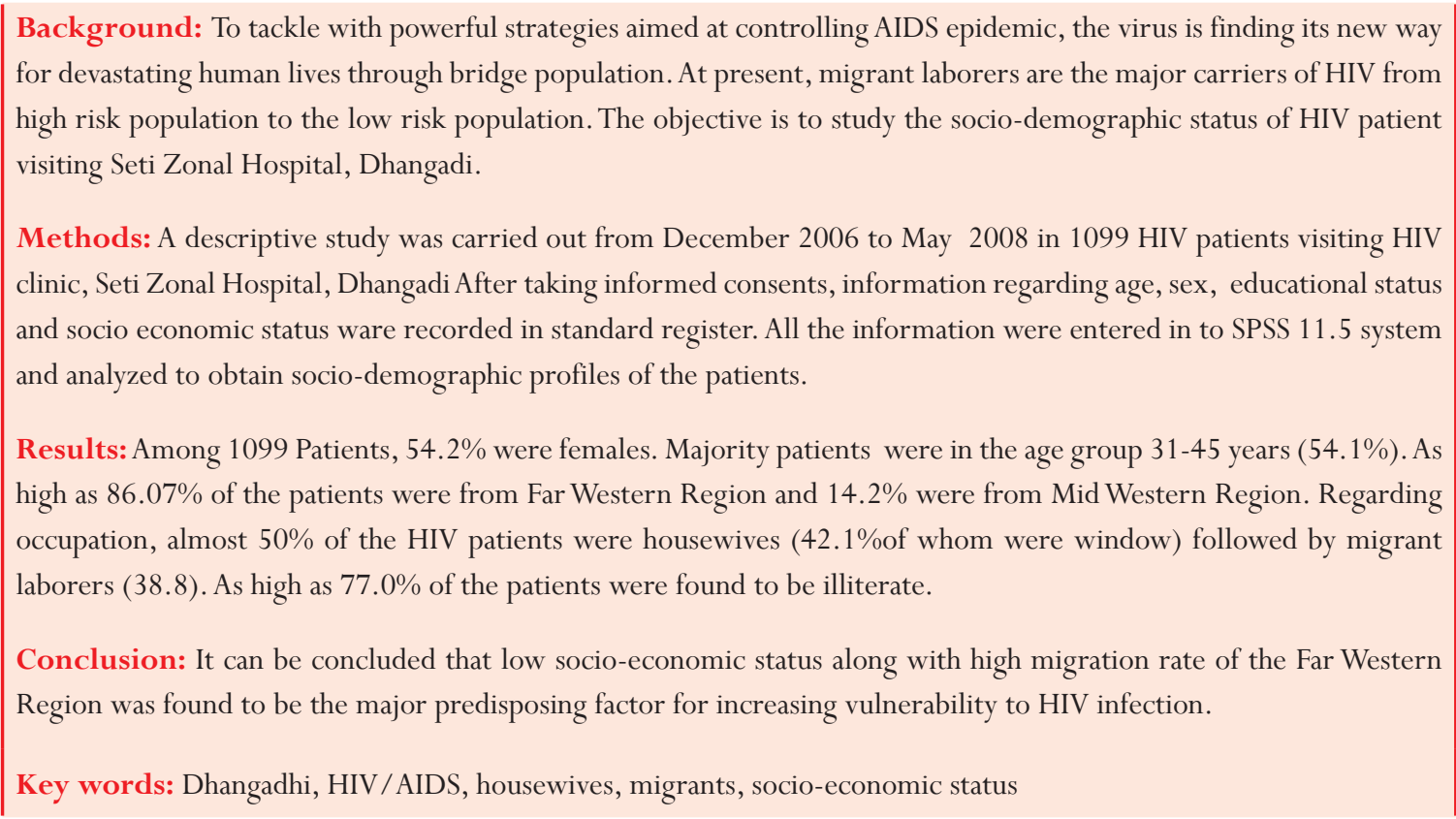

\section{INTRODUCTION}

The epidemiological status of HIV in Nepal changing with time and place ${ }^{1}$. At present, the disease is more prevalent in mobilized communities of recourse poor setting such as Far Western Developmental region of Nepal. This region has 9 districts of which 2 fall in Terai region and the rest hilly mountains. Antiretroviral Therapy (ART) center is located in Seti Zonal Hospital (SZH), Dhangadhi. It is the second biggest ART center (Only after Teku Hospital) and obviously the referral ART center for Far Western Nepal. Due to low socio-economic status, low literacy rate and other adverse situations prevailing in the Far Western Region, many young males of this region find their way to India cities where they acquire HIV infection and during short visit to their home, they transmit the virus to their housewives and these silent population in turn may transmit the virus to other general population leading to the emergence of generalized from of HIV epidemic. ${ }^{1}$

Despite the fact that the first new HIV case in Nepal was detected only some years back i.e. in 1998, its toll is surprisingly higher enough to affect gross socioeconomic status of the nation and posing serious threat to achievement of Millennium Development Goal. By the

Correspondence: Dr. Bidhan Nidhi Paudel, Department of Medicine, Seti Zonal Hospital, Dhangadi, Kailali, Nepal. Phone: 9841042550, Email: bidhan_dr2005@ yahoo.com 
Socio-Demographic Profile of HIV Patients at Seti Zonal Hospital

end of 2007, the number of people living with HIV was estimated to be of 33.2 million [30.6-36.1 million] and that of peopled lying of AIDS to be 2.1 million [1.9-2.4 million] ${ }^{2}$. In context of Nepal, the estimated number of people living with HIV is over 75,000 and as of 12 April 2008, 11,234 HIV cases were reported by official date of National center for AIDS and STD control (NCASC) ${ }^{3}$.

Nepal is experiencing transition in HIV epidemic ${ }^{1}$. Currently, migration is one of the major social factors for the rapid spread of HIV in Nepal. Several bio-behavior as well as HIV seroprevalance studies conducted in Far Western Region of Nepal during different time intervals documented HIV prevalence of 6-10\% among the Mumbai returnee and inferred that this region was major hot spot of HIV population, mainly due to high rate of migration. ${ }^{4,5,6,7}$ On the basis of these data has been realized that migrant population, especially labor migrant to India was recognized as one of the vulnerable group for HIV infection.

In one hand there is rapid spread of HIV in Far Western Region of Nepal and on the other hand there is lack of studies specifically oriented to HIV population of this region. So, this study was carried out in adequate number of HIV patients visiting Seti Zonal Hospital, Dhangadhi with patient coverage through out this region so that result obtained can be generalized with high degree of confidence.

\section{METHODS}

A descriptive study was carried out from December 2006 to May 2008 in 1099 HIV patients visiting HIV clinic, Seti Zonal Hospital, Dhangadi. After taking informed consent, information regarding age, sex, mode of transmission, education and socioeconomic status were recorded in standard register. HIV was diagnosed by Tri dot method. This research was a routine part of Hospital program, funded by Family Health International (FHI). All the information obtained from Laboratory report, hospital record and direct communication with patients were entered into SPSS 11.5 system and analyzed to obtain socio-demographic profiles of the patients.

\section{RESULT}

Among 1099 patients, 54.2\% (596) were females and $45.8 \%$ (503) were males. Majority of the patients were in the age group $31-45$ years $(54.1 \%)$ followed by 15 30 years $(30.2 \%)$, the mean and median age being 30.7 years and 32.6 years respectively. HIV positive children constituted $10.4 \%$ of the total patients as shown in table 1

As high as 86.1 patients were from Far Western Region and majority were from Kailali district $(49.3 \%$ of the total male and $39.3 \%$ of the total female) followed by
Doti $(17.9 \%$ of the total male and $25.3 \%$ of the total female). Similarly, 14.2 of the patients were from Mid Western Region and majority was from Surkhet and Banke district. Few patients were from Central Development region while no patients were from Eastern Development Region as shown in table 2.

Socio-economic status of the patients revealed that almost 50\% were housewives (of whom $42.1 \%$ were widow), $38.8 \%$ were migrant laborers and $10.3 \%$ were dependent children as shown in table 3 .

As high as $77.0 \%$ of the patients were found to be illiterate followed by primary level education (12.9\%) as shown in table 4

The major mode of transmission was found to be sexual contact $(88.3 \%)$ and followed by vertical transmission (10.3\%) as shown in table 5.

\section{DISCUSSION}

This study revealed that Epidemiological status of HIV in Far West Region attained generalized form affecting low risk groups such as women and children. Majority of the studied subjects were illiterate and acquired HIV infection via unsafe sexual practice. Other similar studies have suggested the transition of HIV from high risk group such as female sex workers to low risk populations such as housewife via bridge population such as migrants. Analysis of official data of NCASC between 1988 and 2005 reveled that the percentage of housewife among the total HIV positive women increased every year and it was as high as $78.1 \%$ in 2008 . Through patients' history (obtained during counseling), it was clear that migrant laborers had sexual contact with female sex workers (of the Indian cities) and unknowingly transmitted the virus to their housewives. This pattern of HIV transmission obviously leads to the more number of females (in fact widows) than males in the present scenario. So, although number of migrants were less (due to death in advance stage of HIV), they might have been acting as initial bridge population and were responsible for the emergence of generalized from. Other similar studies have also inferred that migrant are more vulnerable to HIV infection. ${ }^{8,9}$ Table 2 revealed that there was high flow of patients in this ART centre even from Mid Western Region and majority were from Surkhet and Banke district. On the basis of this data it can be suggested that Surkhet or Banke will be the appropriate sites for the establishment of ART centre in order to deliver ART related services to as many as needy individuals. As this finding is based on the study of HIV patients visiting Seti Zonal Hospital, Dhangadhi only, the number can be viewed as a tip of an iceberg and signals the necessity to take the combined effort to overcome the challenge. 


\begin{tabular}{|c|c|c|c|c|c|c|}
\hline \multirow{2}{*}{ Age group (in yrs) } & \multicolumn{2}{|c|}{ Male } & \multicolumn{2}{|c|}{ Female } & \multicolumn{2}{|c|}{ Total } \\
\hline & Number & Percent & Number & Percent & Number & Percent \\
\hline$<15$ & $71 / 56$ & 14.1 & $43 / 38$ & 7.2 & $114 / 153$ & 10.4 \\
\hline $15-30$ & $120 / 117$ & 23.9 & $212 / 210$ & 35.6 & $332 / 317$ & 30.2 \\
\hline $31-45$ & $275 / 250$ & 54.6 & $320 / 295$ & 53.7 & $595 / 950$ & 54.1 \\
\hline $46-60$ & $33 / 30$ & 6.6 & $21 / 20$ & 3.5 & $54 / 50$ & 4.5 \\
\hline$>60$ & $4 / 2$ & 0.8 & 0 & 0 & 4 & 0.4 \\
\hline Total & $503 / 469$ & 45.8 & $596 / 563$ & 54.2 & $1099 / 1032$ & 100 \\
\hline
\end{tabular}

\begin{tabular}{|c|c|c|c|c|c|c|c|}
\hline \multirow[t]{2}{*}{ Regions } & \multirow[t]{2}{*}{ Districts } & \multicolumn{2}{|c|}{ Male } & \multicolumn{2}{|c|}{ Female } & \multicolumn{2}{|c|}{ Total } \\
\hline & & Number & Percent & Number & Percent & Number & Percent \\
\hline \multirow{4}{*}{$\begin{array}{l}\text { Central } \\
\mathrm{N}=6(0.5 \%)\end{array}$} & Kathmandu & 2 & 0.4 & 1 & 0.2 & 3 & 0.3 \\
\hline & Lalitpur & 2 & 0.4 & 0 & 0 & 2 & 0.2 \\
\hline & Dhading & 1 & 0.2 & 0 & 0 & 1 & 0.1 \\
\hline & Nawalparasi & 1 & 0.2 & 0 & 0 & 1 & 0.1 \\
\hline \multicolumn{8}{|l|}{ Mid western } \\
\hline \multirow[t]{8}{*}{$N=156(14.2 \%)$} & Surkhet & 20 & 3.9 & 28 & 4.7 & 48 & 4.3 \\
\hline & Banke & 22 & 4.3 & 18 & 3.0 & 40 & 3.6 \\
\hline & Dailekh & 15 & 3.0 & 9 & 1.5 & 24 & 2.2 \\
\hline & Baradia & 10 & 1.9 & 14 & 2.3 & 24 & 2.2 \\
\hline & Dang & 7 & 1.4 & 10 & 1.7 & 17 & 1.5 \\
\hline & Rolpa & 1 & 0.19 & 0 & 0 & 1 & 0.1 \\
\hline & Kalilkot & 1 & 0.19 & 0 & 0 & 1 & 0.1 \\
\hline & Rukum & 0 & 0 & 1 & 0.16 & 1 & 0.1 \\
\hline \multicolumn{8}{|l|}{ Far western } \\
\hline \multirow[t]{9}{*}{$\mathrm{N}=156(86.1 \%)$} & Kailali & 248 & 49.3 & 238 & 39.9 & 486 & 43.7 \\
\hline & Doti & 90 & 17.9 & 150 & 25.2 & 240 & 21.6 \\
\hline & Acham & 63 & 12.5 & 96 & 16.1 & 159 & 14.3 \\
\hline & Bajura & 2 & 0.4 & 4 & 0.7 & 6 & 0.5 \\
\hline & Baghang & 2 & 0.4 & 2 & 0.3 & 4 & 0.4 \\
\hline & Kanchanpur & 16 & 3.2 & 15 & 2.5 & 31 & 2.8 \\
\hline & Dadeldhur & 4 & 0.8 & 6 & 1.0 & 10 & 0.9 \\
\hline & Baitadi & 6 & 1.2 & 3 & 0.5 & 9 & 0.8 \\
\hline & Darchula & 0 & 0 & 1 & 0.2 & 1 & 0.1 \\
\hline
\end{tabular}




\section{Table 3. Socio-economic status of HIV patients}

\begin{tabular}{|lll|}
\hline Occupation & Number & Percent \\
\hline Housewife* $^{*}$ & 546 & 49.7 \\
Migrant laborer & 46 & 38.8 \\
Dependent children & 114 & 10.3 \\
female sex worker (FSW) & 7 & 0.6 \\
Business (clients of FSW) & 6 & 0.5 \\
\hline
\end{tabular}

$316(57.9 \%)$ were with husband, $230(42.1 \%)$ were widow

\section{Table 4. Education status of HIV patients.}

\begin{tabular}{|lll|}
\hline Education status & Number & Percent \\
\hline Illiterate & 847 & 77.0 \\
Primary Education & 142 & 12.9 \\
Secondary Education & 75 & 6.8 \\
Higher Sec. Education & 25 & 2.4 \\
Bachelor & 10 & 0.9 \\
\hline \hline
\end{tabular}

\section{Table 5. Mode of transmission of HIV infection}

\begin{tabular}{|lll|}
\hline Mode of transmission & Number & Percent \\
\hline Sexual contact & 970 & 88.3 \\
Unknown & 4 & 0.7 \\
Blood contact & 1 & 0.1 \\
Drug user & 10 & 0.9 \\
Vertical transmission & 114 & 10.3 \\
Total & 1099 & 100 \\
\hline \hline
\end{tabular}

\section{CONCLUSION}

On the basis of above finding, it can be concluded that significantly larger population of housewives were infected with HIV and patients history suggested that laborer migrants were acting as the bridge population for HIV/AIDS explosion in Far Western Region of Nepal on the ground of low socioeconomic status and high rare of illiteracy with the similar trend in Surkhet and Banke districts of Mid Western Region. So it is recommended that all the HIV/AIDS related agencies should put a combined effort to address this issue as soon as possible through scaling up of the ART services in other sites along with the adoption of appropriately targeted intervention strategies.

\section{ACKNOWLEDGEMENT}

We would like express our sincere thanks to Dr. Hem Raj Pandey (SZH), Prakash pandey (FHI), (Dr. Subash Sitaula of Familay Health International (FHI), Dr. Santosh Basyal (FHI), Suresh Puri (SZH), Sajana Shah (FHI), Lalmani Adhikari (FHI), Kalpana Bhatta (FHI), Chitra Khanal, Deepa Bhattari and other staffs of SZH and FHI who were directly or indirectly involved in this study.

\section{REFERENCES}

1. Suvedi BK. Transition of HIV epidemic in Nepal. Kathmadnu University Medical Journal. 2006; 4(1) 115-118.

2. World Health. Organization (WHO)/UNAIDS. Report on the Global AIDS epidemic, 2007.

3. National centre for AIDS and STI control (NCASC). Cumulative HIV/AIDS situation of Nepal. Fact sheet updated on 12 April, 2008 .

4. NeaplB.Populationmobilityand spread ofHIV across theindo-Nepal Border J Health Popul Nutr 2007 sept; 25 (3): 267-277.

5. Gurbacharya DL, GurbacharyaVL, HIV prevalence among Nepalese MigrantworkersworkinginNepalandIndiacities.JNepalMed.Assoc 2004; 43: 178-81.

6. Family Health international New Era. HIV/STD prevalence and risk factors among migrant and non migrant mates in Kailali; districts of far western Nepal Kathmandu. Family Health International, 2002; page 26

7. Poudel KC, Jimba M,. Okumura J, JoshiAB, Wakai S. Migrant's risky sexual behaviours in India and at home in far westren Nepal. Trop Med Int Health, 2004 August;9(8):897-903.

8. PoudelKC,JimbaM,OkumuraJ,SherchandJB,JimbaM,Murakamil, Waki S. Mumbai disease in far western Nepal: HIV infection and syphilis among male migrant - returnees and non migrants. Trop Med Int Health, 2003, 8 (10) : 933-9

9. World Health Organization (WHO) UNAIDS. Population mobility and AIDS: Technical update 2001. 